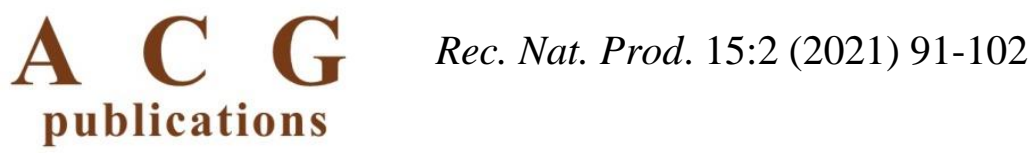

\title{
Chemical Constituents of Tibetan Herbal Medicine Pulicaria insignis and Their in vitro Cytotoxic Activities
}

\section{Xinzhu Wang $\oplus^{1_{*}}$, Peilei Hou $\oplus^{1_{*}}$, Yanbo $Q u \odot^{2}$, Rizhen Huang $\oplus^{1}$, Yan Feng $\oplus^{1}$, Shifeng Zhao $\odot{ }^{1}$, Yeling Ding $\oplus^{1}$ and Zhixin Liao $\odot{ }^{1 *}$}

\author{
${ }^{1}$ Department of Pharmaceutical Engineering, School of Chemistry and Chemical Engineering and Jiangsu \\ Province Hi-Tech Key Laboratory for Biomedical Research, Southeast University, Nanjing, 211189, China \\ ${ }^{2}$ College of Chemistry and Chemical Engineering, Huanggang Normal University, Huanggang, 438000, China
}

(Received June 22, 2020; Revised August 11, 2020; Accepted August 14, 2020)

\begin{abstract}
One new phenolic derivative, 1-(4',5'-dihydroxy-2'-methylphenyl)-pentane-1,4-dione (1), along with eighteen known compounds including eight sesquiterpenoids (2-9), one triterpenoid (10), one bisdpoxylignan (11), one coumarin (12), and seven flavonoids (13-19) were isolated from the dried inflorescence of Tibetan herbal medicine Pulicaria insignis. The structure of $\mathbf{1}$ was established by spectroscopic methods, including HRESIMS, IR, 1D, and 2D NMR. All isolates were assessed for the cytotoxic activities against MGC-803, T24, HepG2, and HeLa cell lines using the MTT assay. The results showed that compound $\mathbf{1}$ displayed moderate cytotoxicity against Hela and HepG2, and compounds 3, 4, 5, 6, and 13 exhibited potential cytotoxic activities against the four cell lines with $\mathrm{IC}_{50}$ values ranging from 3.05 to $14.37 \mu \mathrm{M}$. Notably, compound $\mathbf{5}$ exhibited significant antiproliferative activities against $\mathrm{HepG} 2$ cell lines with the $\mathrm{IC}_{50}$ values of $3.05 \pm 0.36 \mu \mathrm{M}$. Further bioactivity investigation showed that compound $\mathbf{5}$ could block HepG2 cells in the G1 phase of the cell cycle, thereby inhibiting the growth of HepG2 cells and inducing apoptosis in HepG2 cells.
\end{abstract}

Keywords: Pulicaria insignis; chemical constituent; phenolic derivative; cytotoxic activity; sesquiterpenoid. (C) 2020 ACG Publications. All rights reserved.

\section{Introduction}

The genus Pulicaria is an annual or perennial herb belonging to the Compositae family. There are about 100 species of this genus, mainly distributed in Europe, South Africa, and Asia [1]. Some plants of this genus have been used as herbal medicines for anti-inflammatory, analgesic, insect repellent, back-pain, intestinal disorders, and menstrual cramps [2]. In Southern Egypt and Saudi Arabia, the genus Pulicaria was used as an insect repellent and herbal tea [3]. The essential oils from the aerial parts and roots of the genus Pulicaria have antimicrobial, cytotoxic activities, and anti-tyrosine kinase activity [4]. The ethanol extract of Pulicaria could reduce influenza and relieve pain, and possesses antibacterial activity [5-8], cytotoxicity [3,9], anticancer activity [10], and anticonvulsant effect [11].

\footnotetext{
* Corresponding authors: E-mail: zxliao@ seu.edu.cn

$\dagger$ Co-first author: These authors contributed equally to this work.
} 
Pulicaria insignis Drumm. ex Dunn, a perennial herb, grows on the ridge rock in the south of Tibet in China and has been used as a Tibetan medicine for antitussive and soothing liver, clearing blood heat, relieving pain [12]. In recent years, clinical studies demonstrated that $P$. insignis is often used together with other traditional Chinese medicines to make preparations for the treatment of gastric ulcers [13], motion sickness, infantile purulent tonsillitis [14], external auditory canalitis [15], rheumatism [16], and shingles. However, studies on the chemical constituents and pharmacological of $P$. insignis were rarely reported. The compounds isolated from this plant are mainly sesquiterpenes, flavonoids, and diterpenoids [17-19]. Thus, this study aims to investigate the chemical constituents of the inflorescence of $P$. insignis, to screen out bioactive compounds. In this study, one new compound and eighteen known compounds were isolated from the ethanol extract of inflorescence of $P$. insignis. Their structures were identified using HRESIMS, IR, 1D, and 2D NMR spectroscopy, and the in vitro cytotoxic activities were also evaluated.

\section{Materials and Methods}

\subsection{Plant Material}

The inflorescences of $P$. insignis were collected in March 2018 from Xining, Qinghai Province, China. The plant was certificated by RA. Hongfa Sun. A voucher specimen (No. 20180320) was deposited at the Natural Product Chemistry Laboratory, College of Chemistry and Chemical Engineering, Southeast University, Nanjing, China.

\subsection{General}

${ }^{1} \mathrm{H}$ and ${ }^{13} \mathrm{C}$ NMR and 2D NMR spectra were measured on Bruker $600 \mathrm{MHz}$ instruments (Bruker, Karlsruhe, Germany) with TMS as an internal standard. HRESIMS data were obtained from Agilent 6224 MS spectrometer (Agilent Technologies, United States). IR spectra were recorded on an FT-IR 200 instrument (Thermo Fisher, American). UV spectra were recorded on UV-2600 (Shimadzu, Japan). CC (Column chromatography) was performed with silica gel (200-300 mesh, Qingdao Marine Chemical Factory, Qingdao, China), Sephadex LH-20 (Amersham Pharmacia Biotech, Sweden). TLC (Thin-layer chromatography) was conducted on silica gel GF254 plates (Qingdao Marine Chemical Factory). Cancer cell lines were obtained from Shanghai cell bank in the Chinese academy of sciences (China).

\subsection{Extraction and Isolation}

The dried inflorescences of $P$. insignis $(8.0 \mathrm{~kg})$ were extracted with $95 \% \mathrm{EtOH}(50 \mathrm{~L} \times 5)$ three times for $12 \mathrm{~h}$ each time at room temperature. Then the ethanol extracts were combined and concentrated under reduced pressure to obtain a crude extract (818.4 g). The ethanol extract was suspended in $\mathrm{H}_{2} \mathrm{O}$ and partitioned sequentially with petroleum ether (PE), ethyl acetate (EtOAc, EA), and n-butanol ( $n$ $\mathrm{BuOH})$ to yield crude PE $(208.1 \mathrm{~g})$, EtOAc $(158.1 \mathrm{~g})$ and n-butanol $(112.0 \mathrm{~g})$ extracts respectively. The PE extract was subjected to silica gel chromatography eluting with petroleum ether containing increasing amounts of EtOAc (50: 1-0: 1, V: V) to offer seven fractions (Fr.A1-Fr.A7). Fr.A3 was subjected to multiple TLC plate (eluting system PE/EA from 40: 1 to 10: 1, V: V), then separated on silica gel column using a gradient solvent petroleum ether/ EtOAc $(\mathrm{PE} / \mathrm{EA}=20: 1-10: 1, \mathrm{~V}: \mathrm{V})$ to yield twelve subfractions (Fr.A3.1-Fr.A3.12). Fr.A3.9 was further separated on silica gel CC eluting with a gradient solvent of petroleum ether/EtOAc $(\mathrm{PE} / \mathrm{EA}=8: 1-1: 1, \mathrm{~V}: \mathrm{V})$ to afford compound $10(55 \mathrm{mg})$. Fr.A5 was separated on silica gel CC using a gradient solvent of PE/EtOAc (10: 1-6: 1, V: V) to obtain eleven subfractions (Fr.A5.1-Fr.A5.11). Compound $2(8 \mathrm{mg})$ was purified from Fr.A5.9 by silica gel CC eluting with a gradient solvent of PE/EtOAc (20: 1-15: 1, V: V). The mixture Fr.A5.10 was tested for TLC with the eluting system of PE/EtOAc (17: 1, V: V), two points were found on the TLC plate closely, then the mixture was separated on Sephadex LH-20 using methanol as the elution system to afford compounds $\mathbf{3}(10 \mathrm{mg})$ and $\mathbf{4}(8 \mathrm{mg})$. Fr.A6 was separated by silica gel CC with a gradient solvent of PE/EtOAc (10: 1-4: 1, V: V) to yield compound 5 (1000 mg), with the same method Fr.A7 was purified to yield compounds $6(71 \mathrm{mg})$ and $7(367 \mathrm{mg})$. The EtOAc extract was separated by CC with a 
gradient solvent of PE/EA (50: 1-0: 1, V: V) to obtain five subfractions (Fr.B1-Fr.B5). Fr.B2 was separated by silica gel CC eluting with a gradient solvent of $(\mathrm{PE} / \mathrm{EA}=25: 1-7: 1, \mathrm{~V}: \mathrm{V})$ to achieve three subfractions (Fr.B2.1-Fr.B2.3). Fr.B2.1 was purified by silica gel CC eluting with $\mathrm{PE} / \mathrm{CH}_{2} \mathrm{Cl}_{2}$ (4: 1-1: $3, \mathrm{~V}: \mathrm{V})$ to yield compound $\mathbf{8}(735 \mathrm{mg})$. Fr. B3 was eluted with a gradient solvent of PE/EA (10: 1-3: 1, V: V) to obtain five subfractions (Fr.B3.1-Fr.B3.5). By silica gel CC eluting with a gradient solvent of PE/EA (10: 1-8: 1, V: V), Fr.B3.1 was purified to yield yellow powder compound 13 (472 mg), and Fr.B3.2 was purified to afford compounds $11(6 \mathrm{mg}), \mathbf{1 4}(7 \mathrm{mg})$, and $\mathbf{1 5}(13 \mathrm{mg})$ by silica gel CC eluting with a gradient solvent $(\mathrm{PE} / \mathrm{EA}=8: 1-5: 1, \mathrm{~V}: \mathrm{V})$. Compound $16(6 \mathrm{mg})$ was obtained from Fr.B3.3 on silica gel CC with a gradient solvent $(\mathrm{PE} / \mathrm{EA}=5: 1-3: 1, \mathrm{~V}: \mathrm{V})$. Fr.B4 was chromatographed on a silica gel column using a gradient solvent PE/EA (5: 1-1: 3, V: V) to yield five subfractions (Fr.B4.1Fr.B4.5). Fr.B4.1 was purified on a silica gel $\mathrm{CC}$ using a gradient solvent of $\mathrm{CH}_{2} \mathrm{Cl}_{2} / \mathrm{MeOH}$ (100: 1-10: 1, V: V) to afford 17 (32 mg). Fr.B4.2 was further purified using silica gel CC eluting with $\mathrm{CH}_{2} \mathrm{Cl}_{2} / \mathrm{MeOH}(100: 1-5: 1, \mathrm{~V}: \mathrm{V})$ to furnish 9 (12 mg). Fr.B5 was fractionated on a silica gel CC eluting with $\mathrm{CH}_{2} \mathrm{Cl}_{2} / \mathrm{MeOH}$ (100: 1-0: 1, V: V) to obtain sixteen subfractions (Fr.B5.1-Fr.B5.16). After using silica gel $\mathrm{CC}$ with a gradient solvent of $\mathrm{CH}_{2} \mathrm{Cl}_{2} / \mathrm{MeOH}(80: 1-50: 1, \mathrm{~V}: \mathrm{V})$, compound 1 (8 mg) was purified from Fr.B5.6 (2.2 g). Compounds $18(26 \mathrm{mg}), \mathbf{1 2}(13 \mathrm{mg})$, and $\mathbf{1 9}(10 \mathrm{mg})$ were further purified from Fr.B5.10 with a gradient solvent system of $\mathrm{CH}_{2} \mathrm{Cl}_{2} / \mathrm{MeOH}(45: 1-25: 1$, V: V).

\subsection{Spectroscopic Data}

1-(4',5'-dihydroxy-2'-methylphenyl)-pentane-1,4-dione (1): White powder, IR ( $\mathrm{KBr})$ vmax $\left(\mathrm{cm}^{-1}\right)$ : 3421, 1706, 1646, 1365, 1128, 881; UV (MeOH) $\lambda_{\max }(\mathrm{nm}): 312$ (2.75) nm; HR-ESI-MS m/z $223.0972[\mathrm{M}+$ $\mathrm{H}]^{+}$(calcd 223.0970). ${ }^{1} \mathrm{H}$ and ${ }^{13} \mathrm{C}$ NMR data see Table 1 .

\subsection{Cell Culture and Maintenance}

The MGC-803, HeLa, HepG2, T24 cell lines were purchased from the Shanghai cell bank in the Chinese academy of sciences. Culture medium Dulbecco's modified Eagle medium (DMEM), fetal bovine serum (FBS), Antibiotic-Antimycotic, and phosphate-buffered saline (PBS, $\mathrm{pH}=7.2$ ) were from KdyGen Biotech Company (China). Cell lines were grown in the supplemented with $10 \%$ FBS and $1 \%$ Antibiotice-Antimycotic in a humidified atmosphere of $5 \% \mathrm{CO}_{2}$ at $37^{\circ} \mathrm{C}$.

\subsection{In vitro Cytotoxicity Assay}

The antitumor activity of the target compounds was evaluated against four human cancer cell lines (HepG2, T24, MGC-803, and Hela) using the MTT method. About $10 \times 10^{5}$ cells $/ \mathrm{mL}$ of cells in the logarithmic phase were seeded in each well of 96-well plates and incubated for $12 \mathrm{~h}$ at $37{ }^{\circ} \mathrm{C}$ in $5 \%$ $\mathrm{CO}_{2}$. Five different concentrations $(2.5,5,10,20$, and $40 \mu \mathrm{M})$ of compounds were then added to 96well plates, and the cells were incubated at $37{ }^{\circ} \mathrm{C}$ in a $5 \% \mathrm{CO}_{2}$ atmosphere for $48 \mathrm{~h}$. Then added $10 \mu \mathrm{L}$ $5 \mathrm{mg} / \mathrm{mL}$ MTT to each test well and continued incubating for $4 \mathrm{~h}$. The absorbance was recorded on a $570 / 630 \mathrm{~nm}$ double wavelength enzyme labeling instrument. The final $\mathrm{IC}_{50}$ values were calculated by the Bliss method $(n=5)$. HCPT was used as a reference to an organic drug. All the tests were repeated in at least three independent experiments.

\subsection{Apoptosis Analysis}

HepG2 cells in the logarithmic growth phase $\left(1 \times 10^{6}\right.$ cells $\left./ \mathrm{mL}\right)$ were digested and inoculated into 6-well plates and cultured in an incubator with a volume content of $5 \% \mathrm{CO}_{2}$ and a temperature of $37^{\circ} \mathrm{C}$ for $24 \mathrm{~h}$. The next day, after the cells adhered, different concentrations of compound $\mathbf{5}(0,5,10$, and $20 \mu \mathrm{M}$ ) were added according to the group settings. After $48 \mathrm{~h}$ of drug action, cells were digested with $0.25 \%$ trypsin (excluding EDTA) to collect cells. Centrifuge at $1000 \mathrm{rpm} \times 5 \mathrm{~min}$, and then wash the cells with PBS buffer. Add $500 \mu \mathrm{L}$ of binding buffer suspension cells, $5 \mu \mathrm{L}$ Annexin V-FITC to the suspension cells, and then mixed with add $5 \mu \mathrm{L}$ Propidium Iodide. The reaction was performed at room temperature and protected from light, followed by the addition of $100 \mu \mathrm{L}$ of PBS buffer, filtration with a 200-300 mesh filter, and detection of apoptosis by flow cytometry. 


\subsection{Hoechst 33258 Staining}

HepG2 cells in the logarithmic growth phase $\left(1 \times 10^{6}\right.$ cells $\left./ \mathrm{mL}\right)$ were seeded in 6-well plates and cultured in a constant temperature incubator at $37{ }^{\circ} \mathrm{C}$ and $5 \% \mathrm{CO}_{2}$ for $24 \mathrm{~h}$. After treating with compound $5(0,5,10$, and $20 \mu \mathrm{M})$ for being incubated $24 \mathrm{~h}$, the cells were washed with PBS buffer three times. Then we added $0.5 \mathrm{~mL}$ of fixative to the cells at room temperature. After 10 minutes, the fixative was removed, the cells were washed with PBS 3 times every 5 minutes and then stained with an appropriate amount of Hoechst 33258 at room temperature for 10 minutes. After being washed with PBS buffer solution 3 times, the cells were observed under the fluorescence microscope.

\subsection{Cell Cycle Detection}

HepG2 cells in the logarithmic growth phase $\left(1 \times 10^{6}\right.$ cells $\left./ \mathrm{mL}\right)$ were seeded in 6-well plates and cultured in a constant temperature incubator at $37{ }^{\circ} \mathrm{C}$ and $5 \% \mathrm{CO}_{2}$ for $24 \mathrm{~h}$. After treating with different concentrations $(0,5,10$, and $20 \mu \mathrm{M})$ of compound 5 for being incubated $48 \mathrm{~h}$, the cells were collected by digesting with $0.25 \%$ trypsin and washed with PBS buffer. After centrifugation (1000 rpm, $5 \mathrm{~min}$ ), the acquisition of cell pellets was used for the next steps by being resuspended and fixed with 1 $\mathrm{mL}$ of $70 \%$ ethanol at $4{ }^{\circ} \mathrm{C}$ overnight, washed with PBS, and resuspended in $100 \mu \mathrm{L}$ of RNase A for 30 minutes at $37^{\circ} \mathrm{C}$. Finally, the samples were added to $400 \mu \mathrm{L}$ of propidium iodide (PI) stain solution, incubated at $4{ }^{\circ} \mathrm{C}$ in the dark and detect by computer. The red fluorescence was recorded at $488 \mathrm{~nm}$.

Table 1. ${ }^{1} \mathrm{H}$ and ${ }^{13} \mathrm{C}$ NMR data of $\mathbf{1}\left(\delta_{\mathrm{H}}\right.$ in ppm, $J$ in $\left.\mathrm{Hz}, \mathrm{CD}_{3} \mathrm{OD}\right) *$

\begin{tabular}{ccc}
\hline Position & $\boldsymbol{\delta H}(\mathbf{m u l t}, \boldsymbol{J}$ in Hz) & $\boldsymbol{\delta C}$ \\
\hline $1^{\prime}$ & - & 129.5 \\
$2^{\prime}$ & - & 133.3 \\
$3^{\prime}$ & $6.62(1 \mathrm{H}, \mathrm{s})$ & 119.7 \\
$4^{\prime}$ & - & 150.2 \\
$5^{\prime}$ & - & 143.7 \\
$6^{\prime}$ & $7.32(1 \mathrm{H}, \mathrm{s})$ & 118.1 \\
1 & - & 202.2 \\
2 & $3.10(2 \mathrm{H}, \mathrm{t}, J=6.0)$ & 35.5 \\
3 & $2.81(2 \mathrm{H}, \mathrm{t}, J=6.0)$ & 38.3 \\
4 & - & 210.6 \\
5 & $2.21(3 \mathrm{H}, \mathrm{s})$ & 29.9 \\
$7^{\prime}$ & $2.32(3 \mathrm{H}, \mathrm{s})$ & 21.5 \\
\hline
\end{tabular}

${ }^{* 1} \mathrm{H}$ NMR(600 MHz) and ${ }^{13} \mathrm{C}$ NMR $(150 \mathrm{MHz})$

\section{Results and Discussion}

\subsection{Structure Elucidation}

Compound 1, obtained as a white amorphous powder, had a molecular formula of $\mathrm{C}_{12} \mathrm{H}_{14} \mathrm{O}_{4}$ determined by its positive HR-ESI-MS $m / z 223.0972[\mathrm{M}+\mathrm{H}]^{+}(\mathrm{calcd} 223.0970)$, indicating six degrees of unsaturation. IR spectrum showed absorption bands of phenolic hydroxyl $\left(3421 \mathrm{~cm}^{-1}\right)$ and keto carbonyl $\left(1646 \mathrm{~cm}^{-1}\right)$. The ${ }^{1} \mathrm{H}$ NMR spectrum showed six signals, including two aromatic proton singlets at $\delta_{\mathrm{H}} 7.32(1 \mathrm{H}, \mathrm{s})$ and $6.62(1 \mathrm{H}, \mathrm{s})$, two mutual coupling methylenes at $\delta_{\mathrm{H}} 3.10(2 \mathrm{H}, \mathrm{t}, J=6.0 \mathrm{~Hz})$ and $2.81(2 \mathrm{H}, \mathrm{t}, J=6.0 \mathrm{~Hz})$, as well as two methyl singlets at $\delta_{\mathrm{H}} 2.32(3 \mathrm{H}, \mathrm{s})$ and $2.21(3 \mathrm{H}, \mathrm{s})$. The ${ }^{1} \mathrm{H}-{ }^{1} \mathrm{H}$ COSY spectrum showed two $\mathrm{CH}_{2}$ connected signals (Figure 1). Combined with the data from IR, and the amount of hydrogen remaining, the presence of two active protons in the structure was deduced. The ${ }^{13} \mathrm{C}$ NMR spectrum exhibited a total of twelve carbon signals, including two ketone carbonyl carbon 
signals at $\delta_{\mathrm{C}} 210.6$ and 202.2, six aromatic carbons at $\delta_{\mathrm{C}} 150.2,143.7,133.3,129.5,119.7$, and 118.1 assignable to a tetra-substituted benzene ring, as well as two methylenes and two methyl carbons.
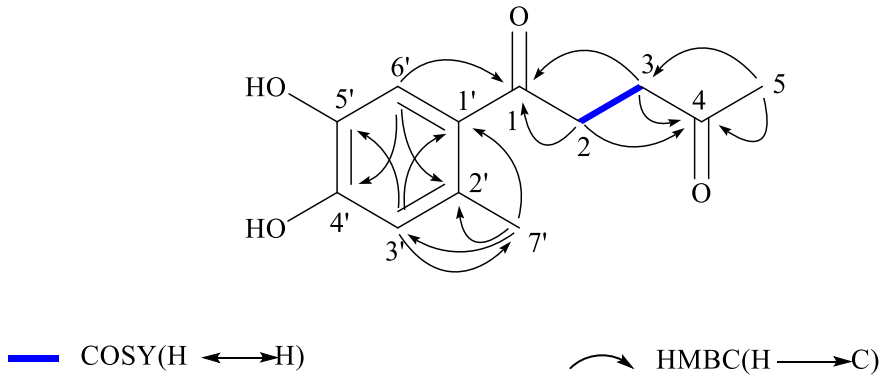

Figure 1. ${ }^{1} \mathrm{H}-{ }^{1} \mathrm{H}$ COSY and Key HMBC correlations of $\mathbf{1}$

In the HMBC spectrum, the correlations from $\mathrm{H} 3-5$ to $\mathrm{C}-3$ and $\mathrm{C}-4$, and from $\mathrm{H} 2-2$ to $\mathrm{C}-1$ and $\mathrm{C}-4$, indicated the presence of 1,4-pentanedione chain (Figure 1). Considering the presence of a benzene ring in compound $\mathbf{1}$, it can be concluded that compound $\mathbf{1}$ was a 1-phenylpentane-1,4-dione derivative. Furthermore, the HMBC correlations from H-6' to C-2', C-4' and C-1, from H3-7' to C-1' and C-3', and from $\mathrm{H}-3^{\prime}$ to $\mathrm{C}-1^{\prime}$ revealed that the methyl $\left(\mathrm{CH}_{3}-\mathrm{7}^{\prime}\right)$ was located at $\mathrm{C}-2^{\prime}$, and the two hydroxy groups were attached at C-4' and C-5. Therefore, the structure of 1 was established as 1-(4',5'-dihydroxy-2'methylphenyl) pentane-1,4-dione. Compound 1 had a rare structure with two phenolic hydroxyls and a 1,4-pentanedione chain. The most similar structure to 1 was henrydione [20]. Two differences between $\mathbf{1}$ and henrydione were that the methyl (C-7') connected to C-2' in $\mathbf{1}$ was absent in henrydione; a $\mathrm{H}$ proton in $\mathrm{C}-2$ of $\mathbf{1}$ was replaced by a hydroxyl in C-2 of henrydione. Apart from henrydione, the structure with a similar skeleton has not been reported to the best of our knowledge. In view of the structural novelty of $\mathbf{1}$, its bioactivity was evaluated.

The known compounds (2-19) were identified as 12-noreudesm-4-ene-3,11-dione (2) [21], $4 \alpha, 5 \alpha$-epoxy-10 $\alpha, 14 \mathrm{H}$-1-epi-inuviscolide (3) [22], 5-oxogermacra-1(10)E,4(15),11(13)-trien-12,8 $\alpha$ olide (4) [23], 2,3-dihydroaromaticin (5) [24], xanthinolide (6) [25], ilicic acid (7) [26], eudesma3,11(13)-dien-12-oic acid (8) [27], 11 $\alpha, 13$-dihydrotomentosin (9) [28], lup-20(29)-ene-3 $\beta, 16 \beta$-diol 3palmitate (10) [29], $9 \alpha$-hydroxypinoresinol (11) [30], aesculetin (12) [31], santin (13) [32], hispidulin (14) [33], eupafolin (15) [34], 3-methylkaempferol (16) [35], 4' ,5,7-trihydroxy-3,6-dimethoxy flavone (17) [36], patuletin (18) [37], and axillarin (19) [38]. All the isolated compounds were identified by comparing with spectral data reported in literatures (Figure 2).

\subsection{Cytotoxic Effects of Isolated Compounds}

MTT assay was used to evaluate the cytotoxic effects of the purified compounds. 10Hydroxycamptothecin (HCPT) was used as a positive control to evaluate the in vitro cytotoxicity potencies of 19 compounds against four human cancer cell lines (Human Gastric Cancer Cell Line MGC-803, Human Cervical Cancer Cell Line HeLa, Human Hepatoma Cell Line HepG2, Human Bladder Cancer Cell Line T24) [39]. The results were summarized in Table 2. As we can see, the new compound 1 exhibited moderate inhibitory effects against Hela and HepG2 cancer cell lines, $\mathrm{IC}_{50}$ values were $58.57 \pm 1.56 \mu \mathrm{M}$ and $50.18 \pm 1.74 \mu \mathrm{M}$, respectively. Because of compound 1 showing no good cytotoxicity against MGC-803 and T24 cell lines $(>100 \mu \mathrm{M})$, we can infer that compound $\mathbf{1}$ has a specific selectivity against human cancer cell lines. Furthermore, compound $\mathbf{1}$ has potential value in further studying the mechanism of cytotoxic activities against the two cancer cell lines Hela and HepG2. Compounds $3,4,5,6$, and 13 showed good activity against all four cancer cell lines, compound 15 showed cytotoxic activity against two cancer lines Hela and HepG2, compound $\mathbf{1 4}$ showed activity only against the Hela cell line. As the results showed from each cell line, compounds 3, 4, and $\mathbf{6}$ inhibited MGC-803 cell line with $\mathrm{IC}_{50}$ values of $9.61 \pm 1.03 \mu \mathrm{M}, 7.04 \pm 0.78 \mu \mathrm{M}$ and $11.28 \pm 0.72 \mu \mathrm{M}$, respectively, the cytotoxicities of compounds $\mathbf{5}$ and $\mathbf{1 3}$ on MGC-803 cells were more remarkable with the $\mathrm{IC}_{50}$ value at $4.29 \pm 0.51 \mu \mathrm{M}, 3.84 \pm 0.17 \mu \mathrm{M}$, respectively, which were lower than that of control 
group HCPT $(6.55 \pm 0.87 \mu \mathrm{M})$. In cytotoxic activities of Hela, compound $\mathbf{1 4}$ showed moderate cytotoxic activity with the $\mathrm{IC}_{50}$ value at $29.48 \pm 2.89 \mu \mathrm{M}$.<smiles>CC(=O)CCC(=O)c1cc(O)c(O)cc1I</smiles><smiles>CC(=O)C1CC[C@]2(C)C(=C(C)C(=O)CCC2C)C1</smiles>

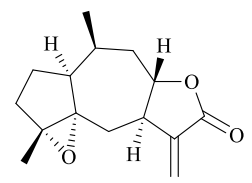<smiles>C=C1CC/C=C(\C)C[C@H]2OC(=O)C(=C)[C@@H]2CC1=O</smiles>

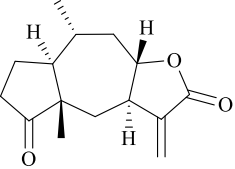<smiles>C=C1C(=O)O[C@H]2C[C@H](C)C(CCC(C)=O)=CC[C@@H]12</smiles><smiles>C=C(C(=O)O)C1CCC2(C)CCC[C@H](C)[C@H]2C1</smiles><smiles>C=C(C(=O)O)C1CCC2(C)CCC=C(C)C2C1</smiles><smiles>CC(=O)CCC1=CC[C@@H]2C(C[C@H]1C)OC(=O)[C@H]2C</smiles>

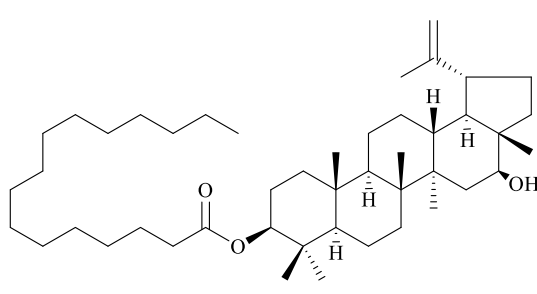

10<smiles>COc1cc([C@@H]2O[C@H](O)[C@H]3[C@@H](c4ccc(O)c(OC)c4)OC[C@H]3[C@@H]2O)ccc1O</smiles><smiles>O=c1ccc2cc(O)c(O)cc2o1</smiles><smiles>COc1ccc(-c2oc3cc(O)c(OC)c(O)c3c(=O)c2OC)cc1</smiles><smiles>COc1c(O)cc2oc(-c3ccc(O)cc3)cc(=O)c2c1O</smiles>

14<smiles>COc1c(O)cc2oc(-c3ccc(O)c(O)c3)cc(=O)c2c1O</smiles>

15<smiles>COc1c(-c2ccc(O)cc2)oc2cc(O)cc(O)c2c1=O</smiles>

16<smiles>COc1c(O)cc2oc(-c3ccc(O)cc3)c(OC)c(=O)c2c1O</smiles><smiles>COc1c(O)cc2oc(-c3ccc(O)c(O)c3)c(O)c(=O)c2c1O</smiles><smiles>COc1c(O)cc2oc(-c3ccc(O)c(O)c3)c(OC)c(=O)c2c1O</smiles>

Figure 2. Chemical structures of compounds 1-19

Compounds with a better performance against Hela were $\mathbf{3}, \mathbf{4}, \mathbf{5}, \mathbf{6}, \mathbf{1 3}$, and $\mathbf{1 5}$, which were all lower than that of control group HCPT $(16.47 \pm 1.24 \mu \mathrm{M})$, among the six compounds, compound $\mathbf{5}$ exhibited the most significant growth inhibitory effects against Hela cancer cell line with the $\mathrm{IC}_{50}$ value at $4.23 \pm 0.39 \mu \mathrm{M}$. In the inhibition effects against HepG2 cell line, compounds $\mathbf{3}, \mathbf{4}$, and $\mathbf{6}$ showed good cytotoxic activities, $\mathrm{IC}_{50}$ values were $6.46 \pm 0.86,5.90 \pm 0.64$, and $9.52 \pm 0.66 \mu \mathrm{M}$, respectively. Compounds 5, 13, and $\mathbf{1 5}$ also inhibited HepG2 cancer cell growth and their inhibitory effects were more apparent than other compounds to be tested, the results were roughly the same as the control group $\mathrm{HCPT}(3.19 \pm 0.46 \mu \mathrm{M})$ with $\mathrm{IC}_{50}$ values at $3.05 \pm 0.36,3.71 \pm 0.44$, and $3.98 \pm 0.29 \mu \mathrm{M}$, respectively. 
In the results of the last cell line T24, compounds $3, \mathbf{4}, \mathbf{5}, \mathbf{6}$, and $\mathbf{1 3}$ showed good cytotoxic activities with $\mathrm{IC}_{50}$ values of $8.33 \pm 0.69 \mu \mathrm{M}, 8.72 \pm 0.75 \mu \mathrm{M}, 5.75 \pm 0.52 \mu \mathrm{M}, 10.77 \pm 0.06 \mu \mathrm{M}$, and $4.78 \pm 0.56 \mu \mathrm{M}$, respectively, which were lower than that of HCPT $(11.83 \pm 1.53 \mu \mathrm{M})$. In conclusion, compound $\mathbf{5}$ always showed significant cytotoxic activity against all four cell lines, and it can provide a more solid theoretical basis for further study on the mechanism of its cytotoxic activity. Meanwhile, compounds $3, \mathbf{4}$, and $\mathbf{1 3}$ showed good cytotoxicities against all four cell lines without selectivity. It was a certain reference value for the in-depth study of their structural characteristics.

Table 2. In vitro cytotoxic activities of compounds in different cancer cell lines

\begin{tabular}{ccccc}
\hline \multirow{2}{*}{ Compounds } & \multicolumn{4}{c}{$\left(\mathbf{I C}_{\mathbf{5 0}}, \boldsymbol{\mu M}\right)$} \\
\cline { 2 - 5 } & MGC-803 & Hela & HepG2 & T24 \\
\hline $\mathbf{1}$ & $>100$ & $58.57 \pm 1.56$ & $50.18 \pm 1.74$ & $>100$ \\
$\mathbf{2}$ & $>50$ & $>50$ & $>50$ & $>50$ \\
$\mathbf{3}$ & $9.61 \pm 1.03$ & $7.12 \pm 0.37$ & $6.46 \pm 0.86$ & $8.33 \pm 0.69$ \\
$\mathbf{4}$ & $7.04 \pm 0.78$ & $5.66 \pm 0.61$ & $5.90 \pm 0.64$ & $8.72 \pm 0.75$ \\
$\mathbf{5}$ & $4.29 \pm 0.51$ & $4.23 \pm 0.39$ & $3.05 \pm 0.36$ & $5.75 \pm 0.52$ \\
$\mathbf{6}$ & $11.28 \pm 0.72$ & $14.37 \pm 1.46$ & $9.52 \pm 0.66$ & $10.77 \pm 0.06$ \\
$\mathbf{7}$ & $>40$ & $>40$ & $>40$ & $>40$ \\
$\mathbf{8}$ & $>40$ & $>40$ & $>40$ & $>40$ \\
$\mathbf{9}$ & $>50$ & $>50$ & $>50$ & $>50$ \\
$\mathbf{1 0}$ & $>40$ & $>40$ & $>40$ & $>40$ \\
$\mathbf{1 3}$ & $3.84 \pm 0.17$ & $4.34 \pm 0.21$ & $3.71 \pm 0.44$ & $4.78 \pm 0.56$ \\
$\mathbf{1 4}$ & $>50$ & $29.48 \pm 2.89$ & $>50$ & $>50$ \\
$\mathbf{1 5}$ & $>50$ & $3.61 \pm 0.14$ & $3.98 \pm 0.29$ & $>50$ \\
$\mathbf{1 6}$ & $>50$ & $>50$ & $>50$ & $>50$ \\
$\mathbf{1 7}$ & $>40$ & $>40$ & $>40$ & $>40$ \\
$\mathbf{1 8}$ & $>40$ & $>40$ & $>40$ & $>40$ \\
$\mathbf{1 9}$ & $>40$ & $>40$ & $>40$ & $>40$ \\
$\mathbf{H C P T}$ & $6.55 \pm 0.87$ & $16.47 \pm 1.24$ & $3.19 \pm 0.46$ & $11.83 \pm 1.53$ \\
\hline
\end{tabular}

${ }^{\mathrm{b}} \mathrm{HCPT}$ was used as a positive control.

\subsection{Effect of compound 5 on apoptosis induction}

To explore the mechanism of cytotoxic activity of compound $\mathbf{5}$ further, the Annexin V-FITC/PI double-staining method was used to quantitatively analyze the apoptosis of HepG2 cancer cells induced by compound $\mathbf{5}$ and then the data were measured by flow cytometry. HepG2 cancer cells were treated with compound 5 at different concentrations of $0,5,10$, and $20 \mu \mathrm{M}$. As shown in Figure 3, few apoptotic HepG2 cell nuclei were detected in the control cells, with the normal condition of $6.84 \%$. After being treated by adding compound $5(5 \mu \mathrm{M})$, significant amounts of apoptosis cells $(16.89 \%)$ were tested. When adding compound 5 to $10 \mu \mathrm{M}, 27.24 \%$ of the cells were induced to enter early-stage apoptosis. When the concentration was increased to $20 \mu \mathrm{M}$, the apoptosis rates were further increased to $44.56 \%$, and the cells were induced to enter into the latestage apoptosis. Hence, the apoptosis detection result suggested that compound $\mathbf{5}$ may induce apoptosis of HepG2 cells in a dose-dependent manner. With the increase of the dosage, more and more cells will enter the apoptosis period. 


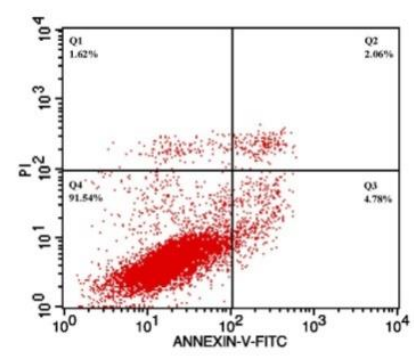

Control

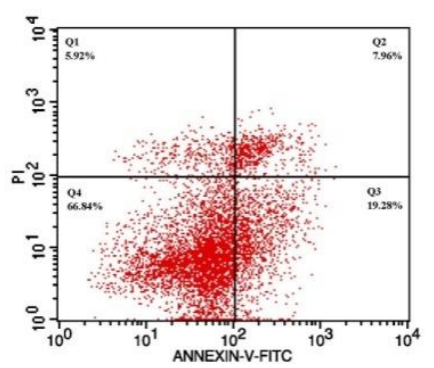

$10 \mu \mathrm{M}$

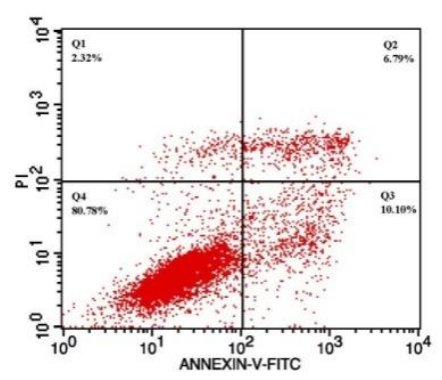

$5 \mu \mathrm{M}$

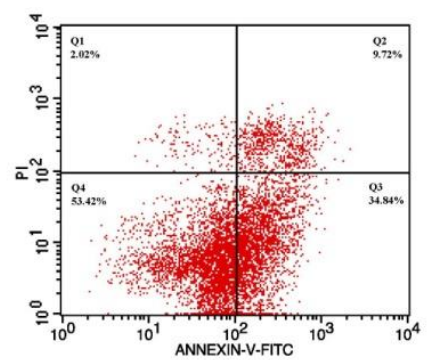

$20 \mu \mathrm{M}$

Figure 3. Cell apoptosis in HepG2 induced by compound 5 (Annexin V-FITC/PI double-staining)

\subsection{Morphological Characterization of Cell Apoptosis of HepG2 Cells by Hoechst 33258}

The important sign of cell apoptosis was the aberrant morphological change of chromatin. The apoptosis effect of compound $\mathbf{5}$ on HepG2 cells was further characterized by Hoechst fluorescence staining. Hoechst 33258 was a blue fluorescent dye that can penetrate cell membranes and had low toxicity to cells. Compound 5 was formulated into four concentration gradients $(0,5,10$, and $20 \mu \mathrm{M})$, and Hoechst 33258 dye was used to stain different concentrations of 5 treated HepG2 cells, which can be observed by a fluorescence microscope (Figure 4), the living cells in the control group showed a uniform light blue fluorescence signal, and with the addition of compound $\mathbf{5}$, a bright blue color began to appear. And with the increase of concentration, bright blue gradually increased, and there were many unstained blank areas. Compared with the control group $(0 \mu \mathrm{M})$, the drug treated cells displayed chromatin condensation, nuclear fragmentation, and the apoptotic formation body, which were the typical morphological characteristics of apoptosis cells. The results showed a dose-dependent relationship, indicating that compound $\mathbf{5}$ induced apoptosis in HepG2 cells, thereby causing nuclear chromatin to aggregate showed a bright blue fluorescent signal. The morphological changes of the HepG2 cells exposed to a series of different concentrations of compound 5 with further proved the inhibitory effects and revealed that HepG2 cells were sensitive to the compound $\mathbf{5}$ which was accorded with the $\mathrm{IC}_{50}$ results. 

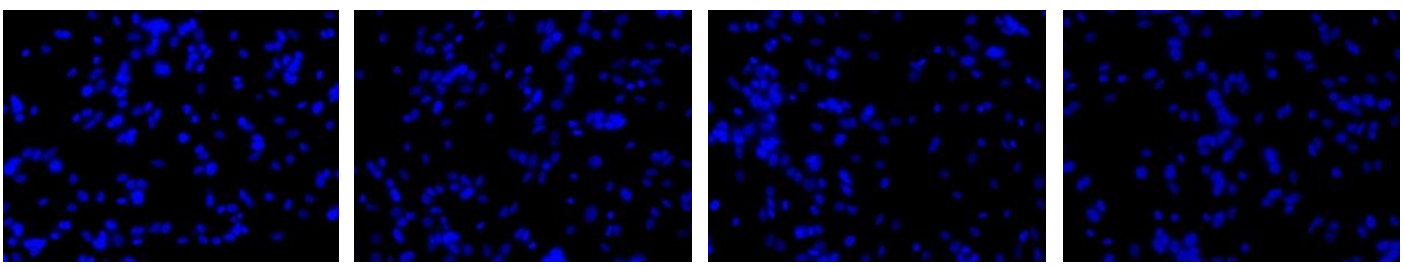

Figure 4. Hoechst 33258 staining of compound 5 in HepG2 cells (from left to right, $0,5,10$, and $20 \mu \mathrm{M}$ )

\subsection{Cell Cycle Analysis}

In order to investigate whether the antitumor activity of was caused by blocking the cell cycle, a classic Propidium Iodide staining (PI staining) method was used to detect the cell cycle of humor cells. Compound $\mathbf{5}$ was chosen to study according to the results of the MTT assay against HepG2 cells. Compared with the control group, HepG2 cells were treated with different concentrations of compound $5(5,10$, and $20 \mu \mathrm{M})$ for 24 hours and then measured by flow cytometry. As shown in Figure 5, with the concentration increased, the DNA content of G1 cells were gradual increased from $49.55 \%$ in the control group to $65.28 \%$. In comparison, the DNA content of cells in the S phase decreased from $25.64 \%$ to $17.86 \%$, and the DNA content in the G2 phase cells also gradually reduced from $24.82 \%$ (Control group) to $16.86 \%(20 \mu \mathrm{M})$. These results indicated that compound 5 blocked HepG2 cells in the G1 phase, thereby inhibiting the growth of HepG2 cells.

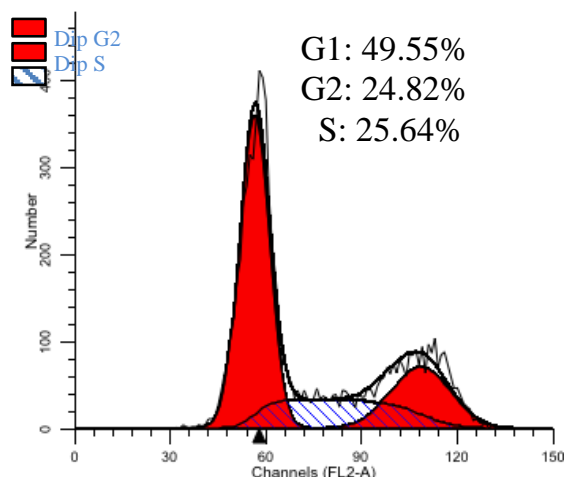

Control

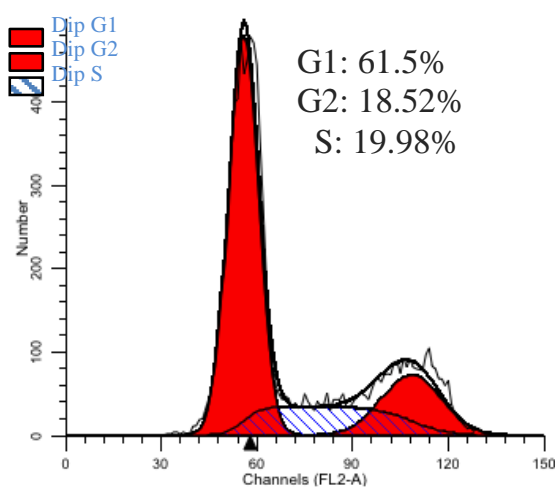

$10 \mu \mathrm{M}$

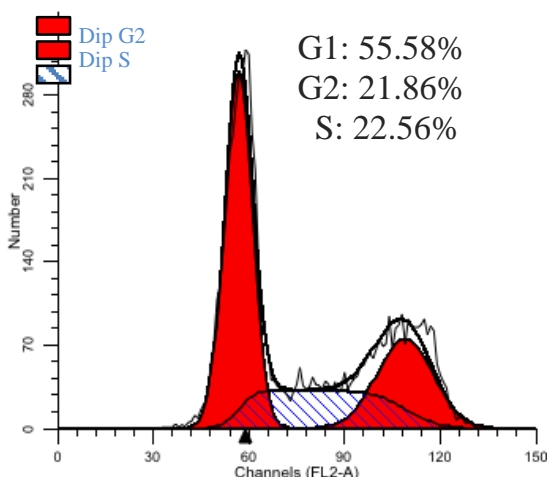

$5 \mu \mathrm{M}$

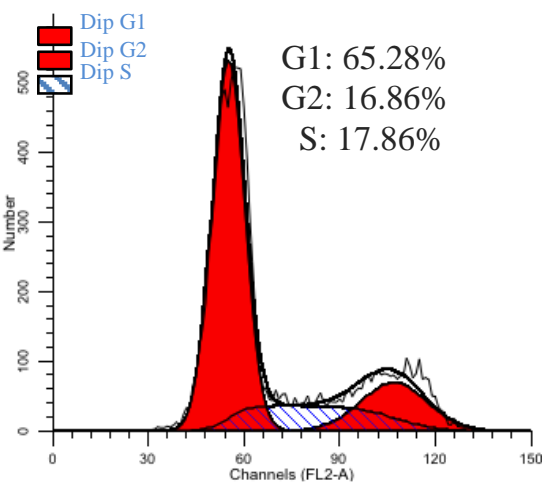

$20 \mu \mathrm{M}$

Figure 5. Cell cycle analysis of compound 5 


\section{Conclusion}

In this study, one new phenolic derivative (1) and eighteen known compounds (2-19) were isolated from the inflorescences of Tibetan herbal medicine $P$. insignis, and their structures were identified based on physical and chemical properties and spectroscopic analysis. Compound $\mathbf{1}$ showed moderate inhibitory activity against Hela and HepG2 cells, compound 5 showed significant cytotoxic activities both in different cell lines and among different compounds in the same cell line, compounds $\mathbf{3}, \mathbf{4}, \mathbf{5}$, and $\mathbf{1 3}$ showed good cytotoxicities against all four cell lines. Among the four compounds, compound $\mathbf{5}$ exhibited the most significant cytotoxic activities against three cancer cell lines (MGC-803, Hela and HepG2) with $\mathrm{IC}_{50}$ values of $4.29 \pm 0.51 \mu \mathrm{M}, 4.23 \pm 0.39 \mu \mathrm{M}$ and $3.05 \pm 0.36 \mu \mathrm{M}$, respectively. The apoptosis detection and morphological characterization results suggested that compound $\mathbf{5}$ may induce apoptosis of HepG2 cells in a dose-dependent manner by causing chromatin condensation, nuclear fragmentation, and the apoptotic formation body. The HepG2 cells were sensitive to compound $\mathbf{5}$, which was accorded with the $\mathrm{IC}_{50}$ results. On the cell cycle progression, compound $\mathbf{5}$ blocked HepG2 cells in the G1 phase, thereby inhibiting the growth of HepG2 cells, suggesting that compound $\mathbf{5}$ had a great potential research value on anti-cancer drug intermediates.

\section{Acknowledgments}

We are grateful to Prof. Hong-Fa Sun of Northwest Institute of Plateau Biology, Chinese Academy of Sciences, Xining, China, for the identification of the plant. This work was supported by the National Natural Science Foundation of China (No.41976109), the Qinghai key R\&D, and the transformation project (Qinghai Science and Technology Department) (No.2017-NK-C25), and the Priority Academic Program Development of Jiangsu Higher Education Institutions (No. 1107047002).

\section{Conflicts of interest}

The authors have no conflict of interest. This publication has not been submitted earlier to any journal and is not being considered for publication elsewhere. All of the authors, including the corresponding authors, have read and approved the final submitted manuscript.

\section{Supporting Information}

Supporting information accompanies this paper on http://www.acgpubs.org/journal/records-ofnatural-products

\section{ORCID}

Xinzhu Wang: 0000-0002-9469-436X

Peilei Hou: 0000-0003-3305-4016

Yanbo Qu: 0000-0003-4885-8631

Rizhen Huang: 0000-0001-6651-5259

Yan Feng: 0000-0002-8033-5163

Shifeng Zhao: 0000-0002-4789-0819

Yeling Ding: $0000-0002-3631-9318$

Zhixin Liao: 0000-0001-6569-366X

\section{References}

[1] M. E. Hegazy, S. Nakamura, W. A. Tawfik, N. S. Abdel-Azim, A. Abdel-Lateff, H. Matsuda and P. W. Pare (2015). Rare hydroperoxyl guaianolide sesquiterpenes from Pulicaria undulata, Phytochem. Lett. 12, 177-181. 
[2] L. Liu, J. Yang and Y. Shi (2010). Phytochemicals and biological activities of Pulicaria species, Chem. Biodivers. 7, 327-349.

[3] M. Stavri, K. T. Mathew, A. Gordon, S. D. Shnyder, R. A. Falconer and S. Gibbons (2008). Guaianolide sesquiterpenes from Pulicaria crispa (Forssk.) Oliv., Phytochemistry 69, 1915-1918.

[4] A. Zardi-Bergaoui, A. Jelassi, M. Daami-Remadi, F. Harzallah-Skhiri, G. Flamini, R. Ascrizzi and H. B. Jannet (2019). Chemical composition and bioactivities of essential oils from Pulicaria vulgaris subsp. dentata (Sm.) Batt. growing in Tunisia, J. Essent. Oil Res. 32, 111-120.

[5] F. E. L. Hanbali, M. Akssira, A. Ezoubeiri, C. E. A. Gadhi, F. Mellouki, A. Benherraf, A. M. Blazquez and H. Boira (2005). Chemical composition and antibacterial activity of essential oil of Pulicaria odora L. J. Ethnopharmacol. 99, 399-401.

[6] A. Ghouil, A. Beyaoui, H. Ben Jannet, B. Hamdi, A. Ben Salah and Z. Mighri (2009). Isolation and structure determination of pulicazine, a new sesquiterpene lactone from the Tunisian Pulicaria laciniata (Coss.et Kral.) Thell., Tetrahedron Lett. 50, 1563-1565.

[7] B. Das, M. R. Reddy, R. Ramu, N. Ravindranath, H. Harish, K.V. S. Ramakrishna, Y. K. Rao, K. Harakishore and U. S. N. Murthy (2005). Clerodane diterpenoids from Pulicaria wightiana, Phytochemistry 66, 633-638.

[8] R. A. A. Mothana and U. Lindequist (2005). Antimicrobial activity of some medicinal plants of the island Soqotra, J. Ethnopharmacol. 96, 177-181.

[9] J. Triana, M. Lopez, F. J. Perez, J. Gonzalez-Platas, J. Quintana, F. Estevez, F. Leon and J. Bermejo (2005). Sesquiterpenoids from Pulicaria canariensis and their cytotoxic activities, J. Nat. Prod. 68, 523-531.

[10] M. A. Al-Yahya, A. M. El-Sayed and J. S. Mossa (1988). Potential cancer chemopreventive and cytotoxic agents from Pulicaria crispa, J. Nat. Prod. 51,621-624.

[11] M. O. M. Tanira, B. H. Ali, A. K. Bashir, I. A. Wasfi and I. Chandranath (1996). Evaluation of the relaxant activity of some United Arab Emirates plants on intestinal smooth muscle, J. Pharm. Pharmacol. 48, $545-550$.

[12] Y. Hu, B. Peng, X. Qi, X. Liu and G. Yu (2010). Comparative assay of superoxide dismutase and total flavone antioxidant activities in leaf-callus and leaves of Ginkgo biloba L., J. Wuhan Botan. Res. 28, 521526

[13] R. Chen and Z. H. Zou (2004). Chinese medicinal preparation for treating gastritis and gastric ulcer, CN $1562122(\mathrm{C})$.

[14] D. M. Xu (2016). Method for treating suppurative tonsillitis of children, CN 105663721 (A).

[15] D. M. Guo (2016). Traditional Chinese medicine preparation for treating otitis externa and preparation method, CN 105641661 (A).

[16] R. Z. Baima (2015). Tibetan medicine compound preparation for treating gout and ostealgia, CN $105106322(\mathrm{~A})$.

[17] J. O. Pares, S. Oksuz, A. Ulubelen and T. J. Mabry F (1981). 6-Hydroxyflavonoids from Pulicaria dysenterica (compositae), Phytochemistry 20, 2057-2057.

[18] J. A. Marco, J. F. Sanz and R. Albiach (1991). Caryophyllene derivatives from Pulicaria dysenterica, Phytochemistry 31, 2409-2413.

[19] J. S. Mossa, I. Muhammad, F. S. El-Feraly, C. D. Hufford, D. R. Mcphail and A. T. Mcphail (1991). Bisabolene and guaiane sesquiterpenes from Pulicaria glutinosa, Phytochemistry 31, 575-578.

[20] Y. Zhao, S. Huang, L. Yang, L. Li, W. Xiao, J. Pu and H. Sun (2008). A new phenyldione from Isodon henryi (Labiatae), Acta Botan .Yunnan. 30, 243-245.

[21] A. G. Hortmann, J. E. Martlnelli and Y. Wang (1969). Synthesis of (-)-1,2.beta.,3,4,4a,5,6,7,8,8a.beta.decahydro-4a.alpha.,8.beta.-dimethyl-7-oxo-2-naphthoic acid methyl ester, J. Org. Chem. 34, 732-736.

[22] J. S. Mossa, F. S. EI-Feraly, I. Muhammad, K. Zaw, Z. H. Mbwambo, J. M. Pezzuto and H. H. S. Fong (1997). Sesquiterpene lactones and rhymol wsters from Vicoa pentanema, J. Nat. Prod. 60, 550-555.

[23] F. Bohlmann, C. Zdero, R. M. King and H. Robinson (1983). Ein weiteres germacranolid mit $\beta$-lactonring aus Grazielia serrata, Liebigs Ann. Chem. 2227-2246.

[24] H. T. Lee, S. W. Yang, K. H. Kim, E. K. Seo and W. Mar (2002). Pseudoguaianolides isolated from inula britannica var. chinenis as inhibitory constituents against inducible nitric oxide synthase, Arch. Pharm. Res. 25, 151-153.

[25] S. Huang, S. Jiang and H. Zhu (2010). Sesquiterpenoids from Tibetan folk drug Pulicaria insignis, Nat. Prod. Res. Dev. 22, 736-739.

[26] J. F. Sanz, G. Castellano and J. A. Marco (1990). Sesquiterpene lactones from Algerian Artemisia herbaalba, Phytochemistry 29, 541-545.

[27] Y. Chen, G. Zhou, L. Liu, Z. Xiong and Y. Li (2001). Enantioselective total synthesis of eudesma3,11(13)-dien-12-oic acid, Synthesis 9, 1305-1307.

[28] R. Lanzetta, G. Lama, G. Mauriello, M. Parrilli, R. Racioppi and G. Soeano (1990). Ichthyotoxic sesquiterpenes and xanthanolides from Dittrichia graveolens, Phytochemistry 30, 1121-1124. 
[29] E. Wenkert, G. V. Baddeley, I. R. Burfitt and L. N. Moreno (1978). Carbon-13 nuclear magnetic resonance spectroscopy of naturally-occurring substances-LVII triterpenes related to lupane and hopane, Org. Magn. Reson. 11, 337-343.

[30] Y. Li, Z. Wang, M. Zhang, S. Luo and J. Chen (2005). A new pinoresinol-type lignan from Ligularia Kanaitizensis, Nat. Prod. Res. 19, 125-129.

[31] G. Zheng and H. Piao (2012). Study on chemical constituents from Potentilla supina, Zhong. Cao. Yao. 43, 1285-1288.

[32] H. I. Abd-Alla, N. M. M. Shalaby, M. A. Hamed, S. El-Rigal, S. N. Al-Ghamdi and J. Bouajila (2016). Phytochemical composition, protective and therapeutic effect on gastric ulcer and $\alpha$-amylase inhibitory activity of Achillea biebersteinii Afan, Arch. Pharm. Res. 39, 10-20.

[33] R. Lu, C. Yang and J. Wei (2011). Chemical constituents of Salvia plebaia, Zhong. Cao. Yao. 42, 859862 .

[34] T. Nagao, F. Abe, J. Kinjo and H. Okabe (2002). Antiproliferative constituents in plants 10. Flavones from the leaves of Lantana montevidensis BRIQ. and consideration of structure-activity relationship, Biol. Pharm. Bull. 25, 875-879.

[35] H. Gao, C. Luo, L. Wang, J. Wang, B. Zheng, Y. Peng and L. Zhou (2012). Preparative separation of 3O-methylkaempferol from Caragana leucophloea by high-speed counter-current chromatography and its antimicrobial activity, J. Med. Plants Res. 6, 2081-2087.

[36] N. M. M. Shalaby, H. I. Abd-Alla, H. H. Ahmed and N. Basoudan (2011). Protective effect of Citrus sinensis and Citrus aurantifolia against osteoporosis and their phytochemical constituents, J. Med. Plants Res. 5, 579-588.

[37] M. A. Abdel-Wahhab, A. Said and A. Huefner (2005). NMR and radical scavenging activities of patuletin from Urtica urens against Aflatoxin $\mathrm{B}_{1}$, Pharm. Biol. 43, 515-525.

[38] O. Barberá, J. A. Marco, J. F. Sanz and J. S. Parareda (1986). 3-Methoxyflavones and coumarins from Artemisia incanescens, Phytochemistry 25, 2357-2360.

[39] X. Liu, J. Yang, X. Yao, X. Yang, J. Fu, L. Bai, L. Liu and Z. Jiang (2019). Linderalides A-D, disesquiterpenoid-geranylbenzofuranone conjugates from Lindera aggregata, J. Org. Chem. 84, 82428247.

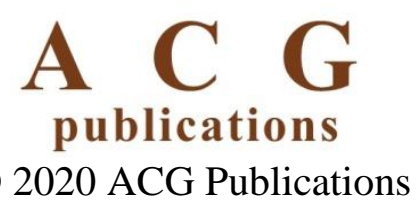

